\title{
The Effect Of Yoga Respiration (Pranayama) on Stress Reduction in The Elderly
}

\author{
Dwi Kusumadewi ${ }^{1}$, Ramelan Sugijana ${ }^{1}$, Wien Soelistya Adi ${ }^{1}$ \\ ${ }^{1}$ Nursing Department, Semarang Health Polytechnic \\ Corresponding author: Kusumadwi56@gmail.com
}

\begin{abstract}
Background : Aging is the process of slowly disappearing the ability of the network to improve itself. One of the mental health problems has by the elderly is stress. If stress is not overcome, it can affect the body's system. One of the ways to deal with stress is yoga respiration (pranayama).

Purpose: The purpose of this study is to determine the effect of yoga respiration (pranayama) on stress reduction in the elderly at Wening Wardoyo Ungaran's Elderly Social Services Home.

Methods: This study used quasy experimental design with one group pretestpost test study design. The sampling technique used was non probability sampling techniques as many as 30 respondents, sample selection used was the DASS 42 questionnaire. The analysis of the data used was the dependent $t$ test / one sample test.

Results: Based on the results of the dependent $t$ test / one sample obtained $\mathrm{p}$ value $=$ 0,000 , it can be concluded that there is an effect of yoga respiration (pranayama) on stress reduction in the elderly at the Wening Wardoyo Ungaran's Elderly Social Services

Home.

Conclusion: Yoga respiration (pranayama) to reduce stress for the elderly and can reduce the stress category of the elderly and score on the 42 DASS questionnaire.
\end{abstract}

\section{Keywords:}

Elderly; Stress; Yoga Respiration; Pranayama

\section{LATAR BELAKANG}

World Health Organitation (WHO) mendefinisikan lansia (masa dewasa tua) dimulai setelah pensiun, antara usia 65 tahun dan 75 tahun. WHO menggolongkan umur lansia menjadi 4 golongan yaitu : usia pertengahan (middle age) adalah 45 - 59 tahun, lanjut usia (elderly) adalah 60 - 74 tahun, lanjut usia tua (old) adalah 75 - 90 tahun dan usia sangat tua (very old) diatas 90 tahun. Menurut UU NO. 13 Tahun 1998, seseorang yang mencapai usia 60 tahun ke atas disebut lanisa (Departemen Kesehatan RI, 2012). Lansia erat kaitannya dengan menua. Menua dalam (Santoso, 2009) adalah proses menghilangnya kemampuan jaringan secara perlahan untuk memperbaiki diri.

Jumlah lansia tahun 2012 di Indonesia mencapai 7,56\% dari total penduduk. Di Jawa Tengah tahun 2012 jumlah lansia mencapai 10,40\% dari jumlah penduduk. Prevalensi lansia di Jawa Tengah mengalami kenaikan dari tahun 2014 yang berjumlah 3,83 juta 
jiwa atau 11,43\% dari seluruh penduduk di Jawa Tengah, ditaun 2015 meningkat mencapai 3,98 juta jiwa atau $11,79 \%$. Jumlah penduduk lansia usia 60 ke atas yaitu 10,34\%. Berdasarkan Data Departemen Sosial (Depsos) menyebutkan jumlah lansia mencapai 9,36\%. Dari studi pendahuluan yang telah dilakukan pada tanggal 15 Oktober 2018 pada Lansia berumur 60 tahun keatas di Rumah Pelayanan Sosial Lanjut Usia Wening Wardoyo Ungaran Kabupaten Semarang pada tahun 2018 terdapat 90 lansia yang terdiri dari laki - laki 27 lansia dan perempuan 63 lansia. Lansia yang kooperatif berjumlah 55 dan yang tidak kooperatif berjumlah 35 lansia. Lansia yang kooperatif dan mengalami stres sebanyak 30 lansia.

Sebuah penelitan pernah dilakukan untuk mengetahui penyebab dan faktor - faktor yang mempengaruhi stres lansia. Hasil penelitian tersebut menunjukan bahwa faktor penyebab terjadinya stres pada lansia dipengaruhi oleh faktor internal dan faktor eksternal. Salah satu faktor internal yaitu perubahan dan keterbatasan pada lansia tersebut meliputi perubahan fisik, perubahan kemampuan motorik, perubahan kemampuan mental, perubahan minat pada usia. Bagi mereka yang telah mempersiapkan dirinya sedini mungkin untuk memasuki masa tua, membuat ia lebih mengerti dan memahami serta dapat menerima segala perubahan dan keterbatasan yang mendadak muncul pada masa lanjut usia. Faktor eksternal meliputi adanya konflik dalam keluarga dan adanya konflik di dalam kehidupan masyarakat maupun komunitas.

Faktor internal dan faktor eksternal yang buruk dapat mempengaruhi kondisi lansia. Dampak dari timbulnya stres pada lansia yaitu akan mengalami kesulitan dalam memanajemen kehidupannya, sebab stres akan memunculkan kecemasan (anxiety) dan sistem saraf menjadi kurang terkendali. Pusat saraf otak akan mengaktifkan saraf simpatis, sehingga mendorong sekresi hormon adrenalin dan kortisol yang akhirnya akan memobilisir hormone hormone lainnya. Kondisi tersebut akan mengakibatkan tekanan darah meningkat dan darah lebih banyak dialihkan dari system pencernaan ke dalam otot-otot, sehingga produksi asam lambung meningkat dan perut terasa kembung serta mual (Bali Yogita dan Ebnezar, 2014). Oleh karena itu, stres yang berkepanjangan akan berdampak pada depresi yang selanjutnya juga berdampak pada gangguan fungsi fisiologis manusia, di antaranya hipertensi, gagal ginjal dan stroke serta berbagai penyakit lainnya.

Kementerian Kesehatan Republik Indonesia menyelanggarakan program pencegahan stres pada lansia yaitu peningkatan dan pemantapan upaya kesehatan para lansia di pelayanan kesehatan dasar, khususnya Puskesmas dan kelompok lansia melalui program Puskesmas Santun Lanjut Usia. Peningkatan upaya rujukan kesehatan bagi lansia melalui pengembangan Poliklinik Geriatri di Rumah Sakit. Peningkatan penyuluhan dan penyebarluasan informasi kesehatan jiwa dan gizi bagi usia lanjut. Berdasarkan program pemerintah tersebut peran perawat berperan penting dalam upaya pencegahan stres yang timbul pada lansia. Selain menjalankan program pemerintah, bentuk penatalaksanan yang dapat dilaksukan untuk mengatasi gejala stres pada lansia yaitu salah satunya dengan pernafasan yoga (pranayama).

Yoga pernapasan (pranayama) merupakan latihan pernapasan dengan tehnik bernapas menggunakan otot-otot diafragma, bernapas dengan cara perlahan dan dalam, sehingga 
dada dapat mengembang penuh dan memungkinkan abdomen terangkat perlahan (Sani, 2012).

Sindhu (2014), mengemukakan bahwa dengan menguasai tehnik pernapasan sama halnya dengan menguasai emosi dan pikiran, melalui napas lembut dan teratur pikiran akan menjadi lebih tenang dan tubuh menjadi lebih rileks dan otot - otot tubuh tidak tegang yang mengakibatkan tubuh santai dan nafas menjadi lambat memberi pengaruh positif terhadap sirkulasi dan jantung untuk beristirahat. Saraf simpatis siap bereaksi menerima pesan aman untuk melakukan relaksasi sedangkan sistem saraf parasimpatik akan memberi respon untuk relaksasi. Selain saraf simpatik, pesan untuk relaksai diterima oleh kelenjar endokrin yang bertanggung jawab terhadap penurunan emosi dan stres pada tubuh.

Yoga pernapasan (pranayama) menjadi salah satu panduan hidup dalam mengelola stres yang bisa dilakukan dimana saja dan kapan saja. Tetapi, pernafasan yoga (pranayama) masih sangat awam didengar oleh masyarakat, masih banyak orang yang beranggapan bahwa yoga hanya dilakukan oleh orang-orang tertentu. Oleh karena itu peneliti tertarik untukmelakukan penelitian tentang "Pengaruh Pernafasan Yoga (pranayama) terhadap penurunan stres pada lansia".

\section{TUJUAN}

Penelitian ini bertujuan untuk mengetahui pengaruh pernafasan yoga (pranayama) terhadap penurunan stres pada lansia di Rumah Pelayanan Sosial Lanjut Usia Wening Wardoyo Ungaran Kabupaten Semarang.

\section{METODE}

Penelitian ini menggunakan desain penelitian quasy eksperimen dengan rancangan one group pretest postest design. Penelitian ini dilakukan di Rumah Pelayanan Sosial Lanjut Usia Wening Wardoyo Ungaran Kabupaten Semarang tanggal 20 Desember 2018 hingga 20 Januari 2019. Populasi pada penelitian adalah seluruh lansia di Rumah Pelayanan Sosial Lanjut Usia Wening Wardoyo Ungaran Kabupaten Semarang sebanyak 90 lansia. Teknik sampling dengan non-probability sampling dengan metode convinience sampling karena teknik pengambilan sampel dengan pertimbangan kemudahan peneliti dalam memilih sampel (Kelana,2011). Penelitian ini mengambil sampel sebanyak 30 lansia yang sesuai dengan kritera inklusi yang ada. Intervensi dilakukan pada satu kelompok yaitu dengan pre test dengan metode wawancara meggunkan kuesioner DASS 42 dilanjutkan dengan perlakuan pernapasan yoga (pranayama) sebanyak 4x dalam 2 minggu kemudian dilakukan post test menggunkakan kuesioner DASS 42 yang sama.

Kriteria inklusi pada penelitian ini adalah lansia dengan stres kategori ringan hingga sedang, lansia berumur 60 tahun keatas di Rumah Pelayanan Sosial Lanjut Usia Wening Wardoyo Ungaran Kabupaten Semarang, dapat berkomunikasi verbal dan bersedia menjadi responden. Instrumen pada penelitian ini adalah subskala stres kuesioner DASS 42 (Depression Anxiety and Stress Scales). Analisa data dengan menggunakan uji wilcoxon dikarenakan data berdistribusi tidak normal. 


\section{HASIL}

Tabel 1 Distribusi Frekuensi Karakteristik Responden di Rumah Pelayanan Sosial Lanjut Usia Wening Wardoyo Ungaran Kabupaten Semarang $(n=30)$

\begin{tabular}{lcc}
\hline \multicolumn{1}{c}{ Karakteristik } & Frekuensi & Presentase \\
\hline Usia & 17 & 56.7 \\
Lansia Muda (60 - 74 tahun) & 13 & 43.3 \\
Lansia Tua (75 -90 tahun) &
\end{tabular}

Jenis Kelamin

Laki - laki

$11 \quad 36.7$

Perempuan

$19 \quad 63.3$

Riwayat Pendidikan

SD

20

66.7

SMP

10

33.3

Riwayat Pekerjaan

Tidak Bekerja

15

Wiraswasta

13.3

Wirausaha

20.0

Petani

Tingkat Stres

Stres Ringan

Stres Sedang

Berdasarkan table 1 diketahui bahwa terbanyak responden berusia 60- 74 tahun (kategori lansia muda). berjenis kelamin perempuan 19 lansia (63.3\%), riwayat berpendidikan SD sebanyak 20 lanisa (66.7 \%) dengan tidak bekerja sebanyak 15 lansia $(50 \%)$ serta memiliki tingkat stres ringan 17 lansia $(56.7 \%)$. 
Tabel 2 Hasil kuesioner data skor stres pada lansia sebelum diberikan perlakuan pernapasan yoga (pranayama)

\begin{tabular}{lcc}
\hline \multicolumn{1}{c}{ Kategori Stres } & Frekuensi & Prosentase \\
\hline Stres Ringan & 17 & 56,7 \\
Stres Sedang & 13 & 43.3 \\
\hline
\end{tabular}

Berdasarkan tabel 2 diatas diketahui bahwa tingkat stres pada lansia sebelum diberikan perlakuan pernapasan yoga (pranyama) yaitu dengan stress ringan sebanyak 17 lansia $(56.7 \%)$ dan stres sedang sebanyak 13 lansia (43.3\%).

Tabel 3 Hasil kuesioner data skor stres pada lansia sesudah diberikan perlakuan pernapasan yoga (pranyama)

\begin{tabular}{lcc}
\hline \multicolumn{1}{c}{ Kategori Stres } & Frekuensi & Prosentase \\
\hline Normal & 10 & 33,3 \\
Stres Ringan & 14 & 46,7 \\
Stres Sedang & 6 & 20,0 \\
\hline
\end{tabular}

Berdasarkan tabel 3 diatas diketahui bahwa tingkat stres pada lansia sesudah diberikan perlakuan pernapasan yoga (pranyama) yaitu yang tidak mengalami stress 10 lansia $(33.3 \%)$, yang mengalami stres ringan 14 lansia $(46.7 \%)$ dan yang mengalami stress sedang yaitu 6 lansia $(20.0 \%)$.

Tabel 4 Hasil analisa stres pada lansia pre dan post perlakuan pernapasan yoga (pranayama)

\begin{tabular}{rcccc}
\hline Perlakuan & $\mathrm{N}$ & Mean & $\mathrm{Z}$ & p value \\
& & & & \\
\hline Pre Test- Post test & 30 & 15.50 & -4.932 & .000 \\
\hline
\end{tabular}

Berdasarkan hasil uji Wilcoxon nilai penurunan stres pada lansia sebelum dan sesudah terapi pernapasan yoga (pranayama) di Rumah Pelayanan Sosial Lanjut Usia Wening Wardoyo Ungaran Kabupaten Semarang, hasil $p$ value $0.000<0.05$ maka Ho ditolak Ha diterima yang artinya ada perbedaan pengaruh stres pada lansia sebelum dan sesudah pemberian pernapasan yoga (pranayama) di Rumah Pelayanan Sosial Lanjut Usia Wening Wardoyo Ungaran Kabupaten Semarang. 


\section{PEMBAHASAN}

Karakteristik responden dalam penelitian ini antara lain meliputi usia, jenis kelamin, riwayat pendidikan, riwayat pekerjaan dan tingkat stres pada lansia sebelum dilakukan perlakuan. Karakteristik responden berdasarkan usia, dari total 30 responden dalam penelitian ini sebagian besar adalah lansia berusia 60 - 74 tahun (lansia muda) yaitu sejumlah 17 responden (56.7\%). Maryam (2011) mengungkapkan bahwa lansia akan lebih mudah mengalami stres dikarenakan lansia mengalami perubahan - perubahan fisik, mental maupun psikologis yang menurun secara.

Karakteristik responden dari 30 lansia berdasarkan jenis kelamin dalam penelitian ini paling banyak adalah responden dengan jenis kelamin perempuan 19 lansia (63.3 \%). Hal ini sesuai dengan teori Roslina Verauli (2017) bahwa semua orang dengan jenis kelamin perempuan maupun laki - laki memiliki potensi stres yang sama namun ada beberapa hal yang membuat stres antara laki - laki maupun perempuan menjadi berbeda yaitu stres yang terjadi pada laki- laki bersifat internalize yang mengarah pada perilaku sementara perempuan externalize dominan dengan emosional. Selain itu, wanita memiliki sifat yang lebih sensitif daripada laki - laki. Hasil penelitian sesuai dengan teori yang telah disebutkan diatas jika antara jenis kelamin perempuan dan laki - laki tidak mengalami perbedaan yang signifikan dari segi frekuensi.

Karakteristik responden berdasarkan riwayat pendidikan paling banyak dari total 30 responden adalah dengan pendidikan terakhir SD sebanyak 20 responden (66.7\%). Pendidikan merupakan suatu hal yang penting dalam kehidupan manusia. Pendidikan adalah suatu proses pembelajaran, ketrampilan, dan kebiasaan sekumpulan manusia yang diwariskan dari suatu generasi ke generasi selanjutnya.Menurut Notoatmodjo, 2010 menyebutkan jika tingkat pendidikan yang cukup akan lebih mudah dalam mengidentifikasi stresor dalam diri sendiri maupun dari luar dirinya. Yunitasari (2012) juga menyebutkan bahwa semakin tinggi tingkat pendidikan yang ditempuh seseorang, semakin rendah individu akan mengalami stres. Hal ini dikarenakan pendidikan menjadikan individu lebih memahami fenomena yang terjadi pada dirinya.

Karakteristik responden berdasarkan riwayat pekerjaan dari total 30 responden adalah tidak bekerja sebanyak 15 responden $(50 \%)$. Berdasarkan penelitian yang dilakukan oleh Nur Hidayaah (2013) menyebutkan jika pekerjaan dapat menjadi salah satu pemicu stres pada lansia. Penurunan kondisi psikis dan fisik berpengaruh pada turunnya produktifitas para lansia. Jika pada waktu mudanya seseorang telah mempersiapkan cukup 'bekal" untuk masa tuanya, maka lansia dapat menikmati masa pensiunnya. Beban kerja yang tidak didukung oleh kondisi fisik dan psikis dapat memicu stres pada lansia. Apalagi adanya tuntutan untuk memenuhi nafkah keluarga. Jika lansia memilih untuk bekerja, maka pilihan pekerjaan yang tidak terlalu berat, tidak bertarget, tidak bersaing, dan tidak ada deadline. Misalnya memilih untuk berternak, bertani, atau berkebun di dekat rumah. Beberapa pekerjaan tersebut sangat baik bagi lansia, selain sehat pekerjaan ini dapat melatih otot untuk berolahraga karena aktivitas dalam bekerja, juga menambah pendapatan bagi keluarga apabila hobi tersebut menghasilkan finansial. 


\section{Tingkat stres sebelum perlakuan pernapasan yoga (pranayama) dan sesudah di berikan perapasan yoga (pranayama)}

Hasil analisa penelitian yang sudah dilakukan didapatkan frekuensi kategori stres sebelum diberikan perlakuan yaitu kategori ringan sebanyak 17 responden (56.7\%), kategori stres sedang sebanyak 13 responden (13.3\%).

Pada responden yang mengalamis stres dengn kategori ringan, ditandai denga responden cenderung gelisah, dan sulit untuk beristirahat. Sedangkan responden yang mengalami stres dengan kategori sedang mudah kesal dengan hal hal yang sepele dan mudah marah. Hal ini sesuai dengan cirri - ciri stres ringan sampai dengan sedang menurut Rasmun tahun 2004. Namun setelah diberikan perlakuan pernapasan yoga (pranayama) selama dua minggu didapatkan hasil dengan kategoris normal 10 responden $(33.3 \%)$, kategori stres ringan 14 responden (46.7\%), kategori stres sedang sebanyak 6 responden $(20 \%)$ dan tidak ada responden dengan kategori stres berat. Dari hasil tersebut , rata rata responden setelah diberikan perlakuan pernapasan yoga (pranayama) mengalami penurunan 1 kategori tingkatan, seperti penurunan dari kategori stres sedang menjadi stres ringan, kategori stres ringan menjadi normal. Namun terdapat 13 responden yang tidak mengalami penurunan kategori tingkat stres hanya saja responden mengalami penurunan skore dalam kuesioner DASS 42. Seperti yang sudah ditentukan di awal penelitian. Jika semakin besar skore yang didapatkan dari kuesioner DASS 42 maka seamakin tinggi kategori stres yang terjadi pada responden. Berdasarkan penelitian didapati yang mengalami penurunan 3 skore kuesioner DASS 42 sebanyak 1 responden dengan kategori stres ringan, yang mengalami penurunan 2 skore sebanyak 2 responden kategori stres ringan, penurunan 1 skore sebanyak 4 responden dengan kategori stres ringan, responden yang mengalami penurunan 2 skore kategori stres sedang sebanyak 4 responden, penurunan 1 skore kategori stres sedang sebanyak 2 responden. Penurunan skore kuesioner DASS 42 terjadi karena beberapa faktor baik karena faktor lingkungan ataupun faktor keadaan.

Pada responden pertama sebelum dan sesudah diberikan pernapasan yoga (pranayama) dengan penurunan 3 skore kategori stres ringan dikarenakan responden merasa masih kurang maksimal dalam mengikuti instruksi pelatih. Responden ke dua dan ketiga sebelum dan sesudah diberikan pernapasan yoga (pranayama) dengan penurunan 2 skore kategori stres ringan karena responden merasa gerakan yang dicontohkan sedikit sulit dan terkadang tidak mengikuti kegiatan secara rutin dan lebih memilih untuk tidur dan beristirahat di kamar. Responden ke empat, lima, enam dan tujuh sebelum dan sesudah diberikan pernapasan yoga (pranayama) dengan penurunan 1 skore kategori stres ringan karena responden merasa gerakan yang dicontohkan sedikit sulit, dan masih ingin segera cepat selesai. Responden dengan inisial Ram, Sur, Tug, Sug sebelum dan sesudah diberikan pernapasan yoga (pranayama) mengatakan bahwa sangat suka mengikuti kegiatan ini hanya saja responden sulit untuk berkonsentrasi secara penuh karena jarak antara responden satu dengan yang lain sangatlah dekat. Responden dengan inisial $\mathrm{Yu}$ dan $\mathrm{Sj}$ sebelum dan sesudah diberikan pernapasan yoga (pranayama) mengatakan bahwa responden sedikit bosan dengan pernapasan yang diajarkan dan kurang menikmati kegiatan yang dilakukan bersama - sama. Hal ini sesuai dengan teori Marta Davis (1995) yang mengatakan jika salah satu untuk mencegah terjadinya stres 
pada lansia yaitu melakukan serangkaian aktifitas dengan metode non farmakologis yang dapat diaplikasikan berupa pernapasan yoga (pranayama). Perapasan yoga (pranayama) ini dilakukan secara teratur dan berkala. Dengan kegiatan ini, lansia dapat memiliki banyak manfaat untuk kebugaran jasmani maupun rohani dan menjalani aktivitas kesehariannya dengan kondisi kesehatan yang baik. Aktivitas yang dilakukan, terutama diluar rumah dapat meningkatkan sikap bersosialisasi mengurangi stres dan rasa kesepian, menjadikan kualitas kesehatan jiwa yang lebih baik dan mencegah terjadinya stres pada lansia.

\section{Pengaruh pernapasan yoga (pranayama) terhadap penurunan stres pada lansia di Rumah Pelayanan Sosial Lanjut Usia Wening Wardoyo Ungaran Kabupaten Semarang}

Berdasarkan uji statstik dengan menggunkan uji wilcoxon dengan jumlah 30 responden tergambar penurunan tingkat kategori stres pre dan post perlakuan dengan dengan nilai signifikansi p-value sebesar $0.000(<0.05)$ maka hipotesis nol $\left(\mathrm{H}_{0}\right)$ ditolak, sehingga dapat disimpulkan bahwa ada pengaruh pernapasan yoga (pranayama) terhadap penurunan stres pada lansia diRumah Pelayanan Sosial Lanjut Usia Wening Wardoyo Ungaran Kabupaten Semarang. Menurut Cramer al (2013) pernapasan yoga (pranayama) dapat menjadi sarana untuk mengurangi stres karena ketika tubuh relaksasi dengan mengatur pernapasan yoga (pranayama) sistem saraf parasimpatik akan merangsang penurunan hormone kortisol dan dapat mengurangi tekanan darah, laju pernapasan dan penurunan laju jantung yang efektif untuk mengurangi stres dan depresi.

Yogita dan Ebnazer (2014) mengatakan bahwa teknik pernapasan yoga (pranayama) dapat meningkatkan kesehatan fisik ataupun mental melalui down regulasi dari hipotalamus, hipofisisadrenal axis dan sistem saraf simpatis (SNS) yang akan dipicu sebagai respon perrmintaan fisik ataupun psikologis. Pernapasan yoga (pranayama) memberi manfaat yaitu memberi suasana hati lebih baik sehingga lansia yang rutin mengikuti kegiatan ini akan senantiasa dalam kondisi perasaan yang nyaman dan tenang. Kondisi perasaan yang nyaman menjadikan individu dapat mengoptimalkan proses mental yang berfungsi dan berpengaruh pada kemampuan individu menghadapi setiap permasalahan yang dapat menimbulkan stres. Terlebih pernapasan yoga (pranayama) dilakukan secara berkelompok dan diiringi musik sehingga memberikan perasaan nyaman dan aman, serta terpicu suatu keceriaan dan kebersamaan. Berdasarkan skore penelitian uji statistik sebelum dan sesudah perlakuan terdapat 7 responden yang mengalami penurunan kategori stress ringan ke normal, kategori stres sedang ke ringan terdapat 1 responden. Berdasarkan penurunan skore stres kuesioner DASS 42 terdapat 13 responden dan tidak mengalami penurunan kategori stres. Seperti yang sudah ditentukan di awal penelitian. Jika semakin besar skore yang didapatkan dari kuesioner DASS 42 maka seamakin tinggi kategori stres yang terjadi pada responden.

Berdasarkan uraian diatas, penelitian yang telah dilakuakan oleh peneliti sama halnya dengan penelitian yang telah dlakukan oleh Canda Rajak tahun 2012 tentang studi kombinasi yoga exercise,pernapasan yoga (pranayama) dan meditasi untuk mengurangi stres di India dengan indicator tekanan darah hasil penelitian menunjukan bahwa yoga exercise, pernapasan yoga (pranayama) dan meditasi berhubungan statik dengan 
tingkat stres yang ditunjukkan dengan uji statistik student $\mathrm{t}$ test dengan nilai $p$ value< 0.05 sehingga dapat disimpulkan bahwa ada pengaruh sebelum dan sesudah pemberian terapi yoga exercise, yoga pranayama dan meditasi terhadap penurunan stres yang terjadi di India.

\section{SIMPULAN}

Ada pengaruh perbedaan skore dan kategori stres pada lansia dengan stres sebelum dan sesudah diberikan perlakuan pernapasan yoga (pranayama). Perlu diberikannya dukungan penuh dari pihak panti dalam setiap kegiatan pernapasan yoga (pranayama) hal ini diharapkan agar lansia dapat melakukan kegitan seara optimal baik dari segi frekuensi ataupun fasilitas yang ada. Dan bagi peneliti selanjutnya diperlukan penelitian lebih lanjut tentang kualitas pernapasan yoga (pranayama) dan dilakukan pada kelompok yang berbeda. Jumlah intervensi dapat di tambahkan untuk hasil yang maksimal. Penelitian ini dapat di jadikan peneliti selanjutnya sebagai evidence based.

\section{REFERENSI}

Bali Yogitha. (2014). Can Yoga be an Effective Tool in Managing Pschological Stress. American Journal of Ethno medicine ; 001- 007

Departemen Kesehatan RI. (2012). Undang - undang Lanjut Usia Nomor 13 Tahun 1998. Jakarta. Diakses 15 September 2018 dari http://www.hukumonline.com /pusatdata/.pdf

Ebnezar. (2014). Can Yoga be an Effective Tool in Managing Pschological Stress?.American Journal of Ethnomedicine.; 001- 007

Kelana. (2011). Metodologi Penelitian Keperawatan. Jakarta : Trans Info Media

Maryam, R. S, Ekasari, M.F., Rosidawati, Jubaidi,A., Batubara, L.(2011) Mengenal Usia Lanjut dan Perawatannya. Jakarta. Salemba Medika; Dari Skripsi, Nurul.Gambaran tentang Kemandirian Lansia dalam Pemenuhan Aktivitas Sehari -hari di Posbindu Desa Sidang Jawa Kabupaten Crebon

Notoatmodjo, S.(2010). Metodologi Penelitian Kesehatan. Jakarta :Rinek Cipta

Rajak C. (2012). A Study Of Combined Effect Of Yoga (Yogic Exercises, Pranayama \& Meditation ) on Hyper-reactivity to Cold Pressor Test in Healthy Individuals.National Journal of Physiology, Pharmacy \& Pharmacology.Vol 2140 $-145$

Rasmun. (2012) Stress Koping dan Adaptasi.Jakarta. Dari Skripsi, Istiqomah. Hubungan Manajemen Stres dengan Tekanan Darah pada Lansia di Kelurahan Tandang Semarang. Skripsi. UNIMUS ; 2016

Roslina Verauli. (2017). "Pengaruh Mendongeng Terhadap Kemampuan Adaptif Anak Keterbelakangan Mental”. Universitas Tarumanegara

Sani, Rachman. (2014).Yoga Untuk Kesehatan. Dahara Prize 
Saxena T., Saxena M. (2014).The Effect of Varoius Breathing Exercise (Pranayama) in Patients With.

Sindhu P. (2014). Panduan Lengkap Yoga :untuk hidup sehat dan seimbang. Bandung. Qanita..Hal : 59-66.

World Health Organization. (2014). The World Health Organization Quality of Life (WHOQOL) $-B R E F$

World Health Organizatin. (2012). Data Global Status Report on Noncommunicable Disease 